\title{
Need and Employees Motivation to Work for NGOs in Thailand
}

\author{
*Matchakarn Ya-Anan, Chanchai Bunchapattanasukda \\ Shinawatra University, Bangkok, 10900, Thailand \\ *matchakarn_mot@hotmail.com
}

\begin{abstract}
This study aims to discuss and explain the level of need and motivation of working employees to work for NGOs in Thailand. How comment can motivate employees to perform as required or to stay in the organization by need. How it can encourage and develop human resource for NGOs in Thailand. Indepth interview was used to collect data from employees of NGOs in Bangkok, Prachuabkireekun Province, Rachaburee Province, Nakornrachasrima Province, Phuket Province, Chiangrai Province, and Chiangmai Province. The data was divided into 11 males and 18 female employees. From the results it is found that, the average of age is 34 years old, working period is 4.5 years, the level need (\%) of physical needs is $62.06 \%$, social needs is $52.58 \%$, self-actualization needs is $51.41 \%$, esteem needs is $51.09 \%$, safety need is $46.84 \%$. From the results it is concluded that different stages of maturity in strategic and operational human resource management exist.
\end{abstract}

Keywords: NGO, motivate, need, Maslow's Theory, human resource management

\section{Introduction}

There are several types of NGOs, and many people work for NGOs that are different in age and level of need. Some of the objectives of NGOs effect working level need. In other way high employees turnover and poor performance have been persistent issues for NGOs. The issues have often been connected to the difficulties in motivating employees. Therefore, commissioned research to look at ways in which these organizations can and do motivate their employees. The growth in the NGO sector in the demands more management attention in encouraging the employees to perform better. NGOs operating in the challenge to raise the motivation of employees or volunteers to perform well and continue to work without leaving their organizations prematurely. The issue consistently high on the list of priorities of non government organizations are employees performance and employees retention. Each NGO has a unique organizational situation despite having a number of common characteristics with others. Different NGOs are at different stages of maturity in strategic and operational human resource management/human resource development. The objectives of the study aim to discuss and identify the level of need of working employees to work for NGOs in Thailand by Maslow's theory. And to comment that how can motivate the employees to perform as required or to stay in the organization by level of need.

\section{Literature Review}

The past research shows that (Andriof et al., 2002, Goodstein and Wicks, 2007) that NGOs have gradually strengthened their influence and this societal evolution has substantially changed the external environment in business. Civil society now expects business to take its responsibilities on an increasing number of issues seriously. Companies can no longer operate independently from their environment.

Thompson (1967); Pfeffer \& Salancik (1978) and Tvedt (2002) found that in some work on organizations, to refer to whatever skills and organizational assets it employs: a method of human rights documentation, an agricultural extension strategy, work with the media, or training, for example, the resource dimension of an organization's existence refers to the need for money and other resources, and the strategies employed to secure them. Many organizational theorists privilege this dimension of organizational life and the flow of resources is often the most visible and readily quantifiable facet of NGOs' interaction with donors and states. Values and mission are the third dimension, emphasized by some scholars and by many organizations themselves as NGOs' distinctive feature. Interpersonal relationships, the fourth dimension, are understudied among NGOs (Edwards and Sen, 2000). Maslow presents these needs in a pyramid form consisting of five levels. He categorized these needs as physiological needs, safety needs, belonging and love, esteem needs and self-actualization needs. These needs are further categorized as deficit needs and being needs. The needs are hierarchically structured and they act as motivators. Their arrangement within the hierarchy depends on the urgency and priority to individuals (Maslow, 1943). 
About twenty years ago, two set of data are available for employment: the 1989 National Statistical Office (NSO) survey and 1989 Chulalongkorn University Research Institute (CUSRI) survey. At the moment, the latter survey is incorporated into a CUSRI data file together with the National Cultural Commission data on registered foundations and associations. The data presented in the fallowing table separate the nonregistered and the registered groups surveyed in 1989. For comparison, data from the NSO survey are also included.

Table 1: Chulalongkorn University Research Institute (CUSRI) survey, 1989

\begin{tabular}{|c|c|c|c|c|c|c|}
\hline \multirow{3}{*}{$\begin{array}{l}\text { No. of } \\
\text { Persons }\end{array}$} & \multicolumn{4}{|c|}{ Registered } & \multicolumn{2}{|c|}{ Non- registered } \\
\hline & \multicolumn{2}{|c|}{ Foundation } & \multicolumn{2}{|c|}{ Association } & \multirow{2}{*}{ workers } & \multirow[b]{2}{*}{ volunteers } \\
\hline & workers & volunteers & workers & volunteers & & \\
\hline $1-5$ & 31 & 19 & 14 & 8 & 86 & 28 \\
\hline $6-10$ & 20 & 11 & 6 & 6 & 40 & 11 \\
\hline $11-20$ & 24 & 4 & 8 & 8 & 27 & 15 \\
\hline $21-50$ & 13 & 13 & 7 & 2 & 17 & 7 \\
\hline More than 50 & 6 & 5 & 6 & 6 & 9 & 5 \\
\hline No information & 43 & 85 & 20 & 35 & 32 & 145 \\
\hline Total & 137 & 137 & 61 & 61 & 211 & 211 \\
\hline
\end{tabular}

Source: Chulalongkorn University Research Institute (CUSRI) survey, 1989, \%of employment classified by type

Table 2: Percent of employment classified by type

\begin{tabular}{lclll}
\hline & Permanent & Temporary & Volunteers & Total \\
\hline Social welfare & 8.4 & 1.1 & 90.5 & 100 \\
Cremation & 11.0 & 3.0 & 86.0 & 100 \\
Commercial & 59.9 & 3.1 & 37.0 & 100 \\
Employer's association & 32.5 & 7.0 & 60.5 & 100 \\
Labor union & 2.5 & 0.4 & 97.1 & 100 \\
Total & $\mathbf{8 . 8}$ & $\mathbf{1 . 3}$ & $\mathbf{8 9 . 9}$ & $\mathbf{1 0 0}$ \\
\hline
\end{tabular}

Source: National Statistical Office (NSO), 1989

Since data are present differently, they cannot directly comparable, one needs to look at them table. Furthermore, because of the different nature of the organization, the degree of voluntarism also differs. Development - oriented organizations need full - time workers to carry out activities while cremation associations rely on volunteers or temporary workers (Amara and Nitaya, 1990). As the twenty years ago, just shown two set of data are: the amount of employees that registered and non- registered and the percent of employment classified by type. However, Rosana Tositrakul told that an influential and widely respected NGO director of a health-service and advocacy NGO, the shift from foreign to domestic funding has taken less than 20 years (Parks, 2008). The five of need levels; (Maslow, 1943),Physiological needs, Safety needs, Belonging and love needs, Esteem needs, Self-actualization needs, that Udechuk, (2009) found that Maslow's need theory is typically described and illustrated as a vertical scale or a pyramid.

This makes the theoretical framework useful as means for measuring some type of satisfaction, particularly job satisfaction. In fact, of the concept of satisfaction is meaningless unless there is some form of measuring or recognizing it. Since needs explain behavior, and behavior reflects attitude. And the past research, Pulasinghage (2010) studied employee motivation: what factors motivate employees to work in nongovernmental organizations (NGO) in Sri Lanka: a study according to Maslow's hierarchy of needs model and found that the factors that motivated the majority of the work force in Sri Lanka to jobs in the nongovernment sector after the Tsunami 2004, The study was aimed to find out how the motivator factors differ among the occupational categories and nongovernmental organization categories. According to the "Maslow's hierarchy of needs" model, employees of United Nations, international organizations and international nongovernmental organizations were at higher motivational levels. Expatriates, national consultants, executives and managerial staff were also highly motivated to work in their respective nongovernmental organizations. And the study recommends that private and the government sector jobs should be upgraded to suite this unemployed workforce. Also getting the data base of level need of working employees to working for NGOs, encourage and develop the human resource management for NGOs in Thailand. 


\section{Research Methodology}

Figure 1: Conceptual Framework of study

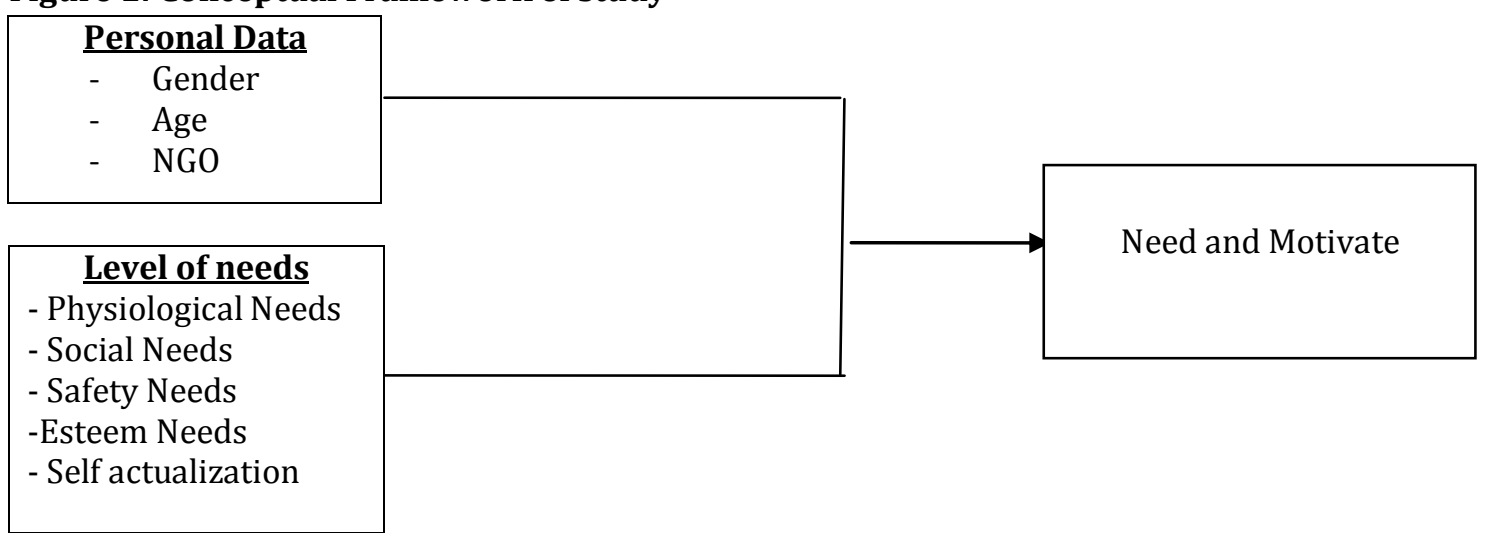

Both secondary and primary data was collected to support the scientific information of the study. Secondary data collection is the method, is initially delivered and processed before getting to the second step of primary data collection. The target population of this research study was the employees who are currently working in NGOs around in Thailand. So the target population of the research study was about 29 employees in Thailand: Bangkok, Prachuabkireekun Province, Rachaburee Province, Nakornrachasrima Province, Phuket Province, Chiangrai Province, and Chiangmai Province. In-depth interview will be use to collect data from employees of NGOs.

An in-depth interview is a qualitative research technique that allows person to person discussion. It can lead to increased insight into people's thoughts, feelings, and behavior on important issues. This type of interview is often unstructured and therefore permits the interviewer to encourage an informant (respondent) to talk at length about the topic of interest. The in-depth interview uses a flexible interview approach. It aims to ask questions to explain the reasons underlying a problem or practice in a target group. The sampling for the qualitative study started with an identification of the sampling units or sampling organization which were administrators among the NGOs in Thailand. The in-depth interviews were applied according to the convenience, networking and snowballing method; which means getting suggestions from one sample for another sample who know each other previously.

\section{Data Analysis and Results}

Table 3: The Results of Need level of employees to work for NGOs in Thailand: Maslow's Theory

\begin{tabular}{lllcccccc}
\hline No & Age & Gender & $\begin{array}{c}\text { Working } \\
\text { Period/ }\end{array}$ & \multicolumn{5}{c}{ Need level of employees to work for NGOs in } \\
\cline { 4 - 8 } & & & year & $\begin{array}{c}\text { Physical } \\
\text { Needs (\%) }\end{array}$ & $\begin{array}{c}\text { Safety } \\
\text { Needs (\%) }\end{array}$ & $\begin{array}{c}\text { Social } \\
\text { Needs (\%) }\end{array}$ & $\begin{array}{c}\text { Esteem } \\
\text { Need (\%) }\end{array}$ & $\begin{array}{c}\text { (\%) Self } \\
\text { Actualization }\end{array}$ \\
\hline 1 & 37 & Female & 2 & 50 & 33 & 100 & 85 & 66 \\
2 & 39 & Male & 2 & 50 & 33 & 50 & 85 & 75 \\
3 & 52 & Female & 3 & 50 & 66 & 100 & 71 & 75 \\
4 & 65 & Female & 8 & 50 & 33 & 25 & 0 & 0 \\
5 & 26 & Female & 2 & 50 & 66 & 100 & 28 & 100 \\
6 & 43 & Female & 1 & 50 & 66 & 75 & 42 & 50 \\
7 & - & Male & 10 & 50 & 66 & 50 & 85.7 & 50 \\
8 & 28 & Female & 7 & 50 & 66 & 50 & 85.7 & 75 \\
9 & 21 & Male & 5 & 50 & 66 & 100 & 71.4 & 50 \\
10 & 22 & Male & 2 & 50 & 66 & 100 & 42.8 & 50 \\
11 & 25 & Female & 6 & 50 & 66 & 25 & 71.4 & 50 \\
12 & 46 & Male & 1 & 50 & 0 & 25 & 0 & 0 \\
13 & 51 & Female & 4 & 50 & 33 & 0 & 100 & 100 \\
14 & 42 & Female & 2 & 50 & 0 & 75 & 85.71 & 50 \\
15 & 58 & Female & 2 & 0 & 66 & 25 & 0 & 50 \\
16 & 32 & Female & 4 & 100 & 33 & 25 & 42.85 & 25 \\
17 & 23 & Female & 3 & 50 & 0 & 100 & 71.4 & 25 \\
18 & 23 & Female & 3 & 50 & 0 & 100 & 57.1 & 50 \\
19 & 36 & Male & 8 & 50 & 66.6 & 75 & 85.7 & 50 \\
20 & 24 & Male & - & 100 & 0 & 25 & 0 & 75 \\
21 & 34 & Female & 6 & 100 & 100 & 100 & 100 & 100 \\
\hline
\end{tabular}




\begin{tabular}{lllcccccc}
\hline 22 & 34 & Female & 13 & 100 & 33.3 & 25 & 42.8 & 25 \\
23 & 27 & Male & 5 & 100 & 100 & 75 & 28.5 & 25 \\
24 & 32 & Female & 4 & 50 & 100 & 50 & 0 & 50 \\
25 & 44 & Female & 9 & 50 & 66.6 & 25 & 71.4 & 25 \\
26 & 39 & Female & 4 & 100 & 33 & 0 & 28.5 & 50 \\
27 & 29 & Male & 5 & 50 & 0 & 0 & 14.2 & 50 \\
28 & 29 & Male & 3 & 100 & 0 & 25 & 0 & 50 \\
29 & 29 & Male & 6 & 100 & 100 & 0 & 85.7 & 50 \\
\hline
\end{tabular}

Physical Needs: As a half of twenty-nine employees they said they need to help the people, but other they doesn't worked to obtain the four necessities of life. The result of physical need is $62.06 \%$. These needs constitute the general well- being of individuals.

Safety Needs: As seven of twenty-nine employees said a little bit of safety needs and in other way they said they don't need a safety needs. However, 10 employees they need a safety, but four employees they strongly need safety. The result of physical need is $46.84 \%$. As for as individuals are concerned these needs relate to living in a safer environment, job and workplace security.

Social Needs: As ten of twenty- nine employees they strongly need a social but four of employees they don't need a social and nine employees they a little bit need social and also four employee's quite need a social. The result of social need is $52.58 \%$. In order to accommodate these needs within the work environment, interpersonal relations arise in work situations as a consequence of this need.

Esteem Needs: The balance of strongly need and not need esteem in nine of twenty-nine employees, but six of them were need but five employees they a little bit need esteem. The result of esteem need is $51.09 \%$. An individual desires to master his or her own work. He or she wants to feel confident, adequate and capable.

Self-Actualization Needs: As two of twenty-nine employees not need self-actualization but, three employees they strongly need and nineteen employees also need while five employees the said a little bit need. The result of self-actualization is $51.41 \%$. These needs reflect the desire to achieve one's potential. It is a complex drive which manifests in different forms in different individuals. It is important to note that not all individuals possess these drives.

\section{Conclusion}

Finally here is some recommendation to the NGOs operating. Facilitate an organizational environment where employees feel valued, and Receive necessary support to realize their potential by contributing to the development of organizational strategies, structures, and processes for improving the effectiveness of organizations. Ensure that organizations have human resource strategies, policies, processes and procedures that focus on aligning employee objectives and organizational goals. Introduce culturally appropriate activities, and processes in the organizations to motivate employees. And consider using a mix of suitable especially level of need of employees to enhance employee motivation and organizational effectiveness. The employees differ in many ways including their capabilities, attitudes, personal goals and personalities. Therefore, behavior and level of need to work for NGOs that difference need level. The high level of need is physical need is 62.06 that according to Maslow' Theory the employees need air, food, drink, shelter, warmth and sex all come under physiological needs. All individuals have these needs and they have to be met. If unfulfilled then individuals would not be motivated to move up the hierarchy.

In other way, different NGOs are at different stages of maturity in strategic and operational human resource. If employees feel that their inputs such as efforts, commitment, loyalty, trust, and enthusiasm to the organization are fairly and adequately rewarded by outputs such as financial and non-financial benefits, they remain motivated and continue to provide inputs towards higher productivity. Employees get de-motivated due to the perceived absence of such equity.

From the result of this study found that the high and low level need for the Maslow's theory to motivate working employees for NGOs. There are the relations between the level needs and the motivate working employees for NGOs. The result can encourage motivation and develop the human resource management (HRM) for NGOs in Thailand. However, the needs are hierarchically structured and they act as motivators. 
Their arrangement within the hierarchy depends on the urgency, priority to individuals and applied to motivate the employees to perform as required or to stay in the NGOs.

\section{References}

Amara, P. \& Nittaya, K. (1990). Thailand Nonprofit Sector and Social Development: ISBN 974-636-7831.

Andriof, J., Waddock, S., Husted, B. S. \& Rahman, S. (2002). Unfolding Stakeholder Thinking: Greenleaf Publishing, Sheffield.

Edwards, M. \& Sen, G. (2000). NGOs, Social Change, and the Transformation of Human Relationships: a $21^{\text {st }}$ Century Civic Agenda. Third World Quarterly, 21(4), 605-16.

Goodstein, J. \& Wicks, A. (2007). Corporate and Stakeholder Responsibility Making Business Ethics a TwoWay conversation. Business Ethics Quarterly 17, 375-398.

Maslow, H. A. (1954). Motivation and Personality. Harper and Brothers, New York.

Maslow, H. A. (1943). A Theory of Human Motivation. Psychological Review, 50, 370-396.

Parks, T. (2008). The rise and fall of donor funding for advocacy NGOs: understanding the impact. Journal of Development in Practice, 18(2) 213-222.

Pfeffer, J. \& Salancik, G. (1978). The External Control of Organizations: Harper \& Row: New York.

Phillips, R. (2005). Australian NGOs: current experiences of corporate citizenship, Journal of Corporate Citizenship, 17, 21-25.

Pulasinghage, C. (2010). Employee Motivation: What Factors Motivate Employees to Work in Nongovernmental Organizations (NGO) in Sri Lanka: A Study According to Maslow's Hierarchy of Needs Model, International Journal of Interdisciplinary Social Sciences, 5(4), 197-212.

Schiller, B. (2005). Business-NGO Partnerships, London: Ethical Corporation.

Thompson, J. D. (1967). Organizations in Action Transaction: Publishers: Somerset.

Tvedt, T. (2002). Development NGOs: actors in a global civil society or in a new international social system? 13(4), 363-375.

Udechukwu, I. (2009). Correctional officer turnover: Of Maslow's needs hierarchy and Herzberg's motivation theory. Public Personnel Management, 38(2), 69-82. 